\title{
MEKANISME KETAHANAN KENTANG (SOLANUM TUBEROSUM) TERHADAP NEMATODA SISTA KUNING (GLOBODERA ROSTOCHIENSIS)
}

\author{
Dewi Fitriyanti ${ }^{1}$, Mulyadi ${ }^{2}$, dan Christanti Sumardiyono ${ }^{2}$
}

\begin{abstract}
Resistance mechanism of potato (Solanum tuberosum) to golden cyst nematode (Globodera rostochiensis). The research was conducted from June 2005 to May 2006 in Kepuhharjo, Cangkringan, Sleman, Yogyakarta. The aims of the research were to find the resistance status of 20 potato varieties, role of chlorogenic acid and caffeic acid in the resistance mechanism and histopathological differences between resistant and susceptible potato varieties to G. rostochiensis. The results showed that two varieties were resistant to G. rostochiensis, i.e, Hertha and Manohara. Thirteen varieties were moderately resistant, i.e; No.30, No.44, No. 5, No.19, Batang Hitam, Agria, Desiree, Berolina, Atlantik, No.095, Cipanas, FLS and Colombus, and five varieties were susceptible, i.e; Kikondo, Granola, Erika, LBR, and Fries. The presence of chlorogenic acid and caffeic acid in Hertha (resistant variety) and in Granola (susceptible variety) were analized by TLC. In Hertha chlorogenic acid was detected at 4, 5, and 6 days after inoculation (DAI), whereas in Granola it was detected at 1 and 6 DAI. It was assumed that the presence of chlorogenic acid for 3 successively week in Hertha, caused it more resistant than Granola. Cell lignification inhibited G. rostochiensis grow well inside the root tissue of Hertha, whereas in Granola only a few cell was lignified as indicated by less absorption of red colour (safranin) in infected areas. Caffeic acid was not detected either in uninoculated or inoculated of both potato varieties. It indicated that caffeic acid might not be naturally present in Hertha and Granola and nematode infection could not stimulate the production of this compound.
\end{abstract}

Key words : Resistance mechanism, potato, Globodera rostochiensis

\section{PENDAHULUAN}

Kentang (Solanum tuberosum) merupakan bahan pangan yang terpenting ke-4 di dunia setelah gandum, jagung dan beras (Rowe, 1993; Spooner \& Barburg, 1994) dan mengandung nilai karbohidrat tertinggi kedua setelah serealia (Jatala \& Bridge, 1990). Di Indonesia kentang juga merupakan komoditas hortikultura yang penting dan telah menjadi bahan pangan alternatif yang dapat menunjang program diversifikasi pangan.

Kentang juga mempunyai kendala di dalam usaha peningkatan produksinya. Salah satu kendala yang dihadapi saat ini adalah serangan nematoda Globodera rostochiensis yang di luar negeri dikenal sebagai Golden Cyst Nematode atau Nematoda Sista Kuning (NSK).

Salah satu cara pengendalian NSK adalah dengan penggunaan varietas tahan. Pengendalian dengan cara ini mempunyai beberapa keuntungan, di antaranya relatif murah bagi petani, dapat memperpendek waktu rotasi pertanaman, dan tidak meninggalkan residu yang toksik (Duncan \& Noling, 1998).
Infeksi nematoda mengakibatkan tanaman mengalami kerusakan atau luka pada jaringannya terutama selama proses migrasi dan perluasan feeding site. Tanaman pada umumnya mengenali dan bereaksi terhadap adanya parasit atau patogen yang masuk dengan cara mengaktifkan respon ketahanannya. Tanaman yang mengalami gangguan atau stres baik akibat kerusakan mekanis atau infeksi jamur, bakteri, virus termasuk nematoda, dapat menstimulasi metabolisme senyawa fenolat (Kosuge, 1969). Senyawa fenolat yang dibentuk sebagai respon tanaman yang mengalami luka pada umumnya ditunjukkan oleh peningkatan sintesis turunan-turunan asam sinamat yaitu asam klorogenat dan asam kafeat (Rhodes \& Wooltorton, 1978). Secara umum asam klorogenat dan asam kafeat yang berfungsi menahan serangan mikroorganisme merupakan prekursor lapisan pelindung yang disintesis di dekat kerusakan dan prekursor dalam biosintesis lignin (Harborne, 1987).

Ketahanan varietas kentang terhadap NSK di Indonesia belum banyak dikaji, termasuk mekanisme ketahanannya. Berdasarkan hal tersebut, maka perlu dilakukan kajian mengenai mekanisme ketahanan

\footnotetext{
${ }^{1}$ Jurusan Hama dan Penyakit Tumbuhan, Fakultas Pertanian, Universitas Lambung Mangkurat, J1. Jend A. Yani Kotak Pos 1028 Banjar Baru

${ }^{2}$ Jurusan Perlindungan Tanaman, Fakultas Pertanian, Universitas Gadjah Mada, Bulaksumur Yogyakarta 55281
} 
varietas kentang terutama keterlibatan asam klorogenat dalam menurunkan populasi NSK.

\section{METODE PENELITIAN}

Percobaan dilaksanakan di Desa Bebeng, Dukuh Kopeng, Kelurahan Kepuhharjo, Kecamatan Cangkringan, Kabupaten Sleman, Daerah Istimewa Yogyakarta dan di Laboratorium Nematologi dan Laboratorium Toksikologi Pestisida Fakultas Pertanian Universitas Gadjah Mada dari bulan Juni 2005 sampai dengan bulan Mei 2006.

Perlakuan dalam percobaan ini disusun berdasarkan Rancangan Acak Lengkap (RAL) yang terdiri atas 20 varietas kentang yaitu kentang varietas 385130.11/FLS-5 (FLS); Colombus (COL); Batang Hitam (BH); Cipanas (CIP); Manohara (MAN); 720050/Kikondo (KIK); 1-1085/Erika (ERI); Hertha (HER); Agria (AGR); MF-11/Fries (FRI) ; No. 095; Desiree (DES); Lbr 40 (LBR); Atlantik (ATL); Berolina (BER); Granola (GRA) ; No.5 : No. 19; No.30; dan No. 44.

Penanaman 20 varietas kentang. Benih 20 varietas kentang ditanam dalam polibag yang telah diisi dengan tanah steril dan pupuk kandang dengan perbandingan $8: 1$. Setiap perlakuan diulang sebanyak 10 kali. Inokulum yang digunakan adalah sista dari NSK yang diambil dari tanah pertanaman kentang di Karang Tengah, Batur, Banjarnegara pada ketinggian tempat \pm $1800 \mathrm{~m}$ dpl. yang diketahui terserang NSK. Ekstraksi dan isolasi sista dalam tanah menggunakan metode Flotasi.

Inokulasi. Inokulasi 50 sista NSK ke sekeliling daerah perakaran kentang dilakukan 1 minggu setelah tanam. Sampel tanah dan akar diambil pada saat tanaman berumur 50 hari setelah diinokulasi dengan NSK.

Pengamatan populasi nematoda. Pengamatan dilakukan terhadap (1) Populasi NSK (sista NSK) dalam $20 \mathrm{~g}$ tanah; (2) Populasi NSK yang menempel di akar, dan (3) Populasi NSK dalam jaringan akar (1 g). Sista yang ada di dalam tanah diekstraksi dan diisolasi menggunakan metode Shurtleff \& Averre (2000). Perhitungan jumlah sista di dalam tanah dilakukan dengan mengambil sampel tanah sebanyak 20 g kemudian disaring 2 kali menggunakan saringan berukuran 840 $\mu \mathrm{m}$ dan $250 \mu \mathrm{m}$ (Fleg \& Hooper, 1986). Sista dipindahkan ke kertas saring yang diletakkan di atas saringan kasa, diratakan dengan alat semprot, dibiarkan kering, kemudian dihitung.

Larva stadium 2 nematoda betina dan jantan dalam jaringan akar dihitung dengan cara pengecatan jaringan akar menggunakan metode Byrd et al. (1983). Akar dicuci dengan hati-hati, kemudian nematoda betina dan sista yang menempel dihitung jumlahnya. Air cucian yang digunakan untuk mencuci akar ditampung, nematoda betina dan sista yang tertampung kemudian disaring dengan menggunakan metode Shurtleff \& Averre (2000). Nematoda betina dewasa dan sista yang tersaring kemudian dihitung jumlahnya. Hasil perhitungan nematoda betina dan sista yang menempel pada akar dan yang diperoleh dari air cucian akar digabung sebagai populasi betina dan sista yang menempel pada akar.

Analisis data. Data hasil pengamatan populasi nematoda tersebut dianalisis dengan ANOVA dan kemudian dilanjutkan dengan Uji Jarak Ganda Duncan (UJGD) pada taraf 5\%.

Penentuan Kategori Ketahanan. Kategori ketahanan varietas kentang terhadap NSK pada penelitian ini didasarkan pada metode yang dideskripsikan oleh Castillo et al. (1978). Tingkat kepadatan populasi NSK diekspresikan ke dalam rerata indeks populasi NSK. Setiap huruf hasil analisis statistik tiap perlakuan pada masing-masing parameter pengamatan ditentukan jumlah hurufnya yaitu dari huruf pertama (a) sampai huruf terakhir, kemudian ditentukan skor untuk huruf-huruf itu dengan skor tertinggi (a) yang sama yaitu 25. Skor huruf berikutnya ditentukan dengan membagi skor tertinggi (25) dengan jumlah huruf yang ada. Huruf ae mempunyai interval 5 , untuk huruf $\mathrm{a}-\mathrm{f}$ intervalnya 4, dan a - g intervalnya 3 . Indeks populasi masingmasing parameter pengamatan selanjutnya ditentukan dengan cara menjumlahkan skor yang ada pada huruf dan membaginya dengan jumlah huruf pada masingmasing perlakuan. Rerata indeks populasi NSK diperoleh dengan menjumlahkan indeks populasi dari masingmasing parameter pengamatan dan membaginya dengan jumlah parameter pengamatan (4). Nilai rerata indeks populasi yang tertinggi dibagi dengan 3 kategori ketahanan merupakan interval untuk menentukan kategori ketahanan, yaitu tahan (T), moderat (M) dan rentan (R). Rerata indeks populasi yang tertinggi adalah 21,12 populasi dan interval untuk setiap kategori ketahanan adalah 7,04, dengan demikian varietas kentang yang dikategorikan tahan $(\mathrm{T})$ adalah varietas 
dengan rerata indeks populasi dari $0-7,04$; moderat (M) dari 7,05 - 14,08 dan rentan (R) dari 14,09 21,12 populasi NSK.

Penanaman varietas tahan dan rentan. Satu varietas yang mewakili varietas yang tergolong tahan dan rentan ditanam kembali untuk selanjutnya digunakan untuk analisis asam klorogenat dan asam kafeat serta pengamatan histopatologi. Masing-masing varietas ditanam dalam polibag yang telah diisi dengan tanah steril dan pupuk kandang dengan perbandingan $8: 1$. Jumlah masing-masing varietas adalah 60 tanaman sehingga seluruh tanaman beserta kontrol adalah 240 tanaman. Inokulasi 50 sista NSK ke sekeliling daerah perakaran kentang dilakukan 1 minggu setelah tanam. Inokulum yang digunakan adalah sista NSK yang diambil dari tanah pertanaman kentang di Karang Tengah, Batur, Banjarnegara pada ketinggian tempat $\pm 1800 \mathrm{~m} \mathrm{~d}$. p. 1 .

Analisis asam klorogenat dan asam kafeat. Analisis asam klorogenat dan asam kafeat pada kentang sampel dilakukan pada umur 1-6 minggu setelah diinokulasi dengan G. rostochiensis. Akar kentang ditimbang sebanyak 20 gram kemudian digerus. Setelah halus, gerusan akar diekstraksi dengan menggunakan sohklet dalam etanol $80 \%$ selama 4 jam. Hasil ekstraksi disentrifugasi dengan 3000 putaran selama 5 menit kemudian larutan jernihnya diambil dan dirotavor hingga hampir habis, dan diberi etanol murni sehingga menjadi $5 \mathrm{ml}$. Sebanyak $1 \mathrm{ml}$ larutan ekstrak diambil dan diuapkan sampai volume menjadi 1/3 dari volume semula (Harborne, 1987). Larutan standar yang digunakan adalah larutan asam klorogenat dan asam kafeat dengan konsentrasi $0,4 \%$ (4000 ppm) dalam etanol $80 \%$ (Harborne, 1987). Larutan pengembang yang digunakan adalah asam format : air : etil asetat $(2: 9: 10)$. Pemisahan senyawa dilakukan dengan metode Thin Layer Chromatography (TLC).

Pengamatan histopatologi. Untuk pengamatan histopatologi, pengambilan sampel dilakukan pada umur 6 minggu setelah inokulasi yaitu pada varietas tahan dan rentan yang bagian akarnya ditempeli oleh sista berwarna kuning. Prosedur histopatologi akar dilakukan dengan menggunakan metode parafin (Johansen, 1940).

\section{HASIL DAN PEMBAHASAN}

Skrining Ketahanan. Hasil pengamatan populasi nematoda sista pada 20 varietas kentang menunjukkan adanya perbedaan ketahanan yang signifikan, hal ini ditunjukkan oleh kepadatan populasi NSK yang beragam pada tiap varietas (Tabel 1).

Berdasarkan kategori ketahanan tersebut, maka diperoleh 2 varietas yang tergolong tahan, yaitu varietas Hertha dan Manohara; 13 varietas tergolong moderat yaitu varietas No. 30 , No. 44, No. 5, No. 19, Batang Hitam, Agria, Desiree, Berolina, Atlantik, No. 095, Cipanas, FLS dan Colombus dan 5 varietas tergolong rentan yaitu varietas Kikondo, Granola, Erika, LBR, dan Fries (Tabel 2).

Spesifisitas nematoda terhadap tanaman sebagai inangnya maupun perbedaan-perbedaan di dalam reaksi varietas-varietas tanaman terhadap nematoda akan mempengaruhi besarnya populasi nematoda (Castillo et al., 1978).

Asam Klorogenat dan Asam Kafeat. Analisis senyawa fenolat yang terdapat pada varietas Hertha (Tahan) dan Granola (Rentan) dilakukan dengan menggunakan metode pemisahanan Thin Layer Chromatography (TLC). Ada tidaknya senyawa yang dibentuk pada sampel diketahui dari nilai $\operatorname{Rf}$ (Retention Factor) yang dihasilkan setelah diamati di bawah lampu UV. Selisih jarak yang ditempuh noda dengan jarak yang ditempuh larutan pengembang $(14 \mathrm{~cm})$ merupakan Retention factor ( $\mathrm{Rf})$. Rf yang sama menunjukkan adanya senyawa yang sama.

Besarnya nilai Rf yang dihasilkan oleh standar asam klorogenat dan asam kafeat (sebesar $0,4 \%$ ) juga varietas Hertha dan Granola setelah diinokulasi dengan G. rostochiensis dapat dilihat pada Tabel 3.

Tabel 3 menunjukkan bahwa asam klorogenat ditemukan pada varietas Hertha dan Granola baik sebelum maupun sesudah inokulasi dengan G. rostochiensis. Asam klorogenat pada varietas Hertha ditemukan pada umur 1 minggu dan 2 minggu setelah inokulasi. Adanya asam klorogenat sebelum diinokulasi menunjukkan bahwa ke-2 varietas ini secara alamiah sudah memiliki senyawa asam klorogenat dalam jumlah tertentu di dalam tubuhnya.

Respon tanaman yang mengalami luka pada umumnya ditunjukkan oleh peningkatan sintesis turunanturunan asam sinamat. Senyawa-senyawa ini dapat ditemukan pada tanaman yang sehat maupun sakit, dan akumulasinya distimulasi oleh luka. Senyawa turunan asam sinamat yang paling banyak terakumulasi pada keadaan demikian adalah asam klorogenat dan asam kafeat (Rhodes \& Wooltorton, 1978).

Asam klorogenat pada varietas Hertha terdeteksi pada umur 4,5, dan 6 minggu setelah diinokulasi dengan G. rostochiensis, sedangkan pada varietas Granola 
Tabel 1. Rerata populasi nematoda sista kuning 50 hari setelah inokulasi (hsi)

\begin{tabular}{|c|c|c|c|c|c|}
\hline No & Kode Varietas & $\begin{array}{l}\text { Sista dalam } \\
20 \mathrm{~g} \text { tanah }\end{array}$ & $\begin{array}{l}\text { Sista menempel } \\
\text { pada akar }\end{array}$ & $\begin{array}{l}\text { L3 dan L4 } \\
\text { (1 gr akar) }\end{array}$ & $\begin{array}{l}\text { Nematoda } \\
\text { dalam akar }\end{array}$ \\
\hline 1 & FLS & 3,1 & 5,5 & $3,6 \mathrm{~cd}$ & 4,0 cde \\
\hline 2 & DES & 4,7 & 8,1 & 0,7 cde & 2,9 cdefg \\
\hline 3 & ERI & 8,8 bcde & 12,5 & 1,6 cde & $7,4 \mathrm{a}$ \\
\hline 4 & $\mathrm{BH}$ & 6,6 cde & 5,3 & 1,0 cde & 1,1 \\
\hline 5 & FRI & 8,0 bcde & $34,4 \mathrm{ab}$ & $11,0 \mathrm{a}$ & $3,0 \quad$ cdefg \\
\hline 6 & GRA & 11,2 abcd & 24,5 bcd & 3,4 cde & $7,1 \mathrm{ab}$ \\
\hline 7 & HER & 2,4 & 3,4 & 0,4 de & 0,2 \\
\hline 8 & LBR & 8,1 bcde & $35,5 \mathrm{ab}$ & $6,7 \mathrm{~b}$ & 3,7 cdef \\
\hline 9 & MAN & 6,2 cde & 4,9 & 0,3 & 0,0 \\
\hline 10 & ATL & 6,0 cde & 12,0 & 2,9 cde & 1,0 \\
\hline 11 & CIP & 4,3 & $28,5 \mathrm{abc}$ & 0,6 cde & 0,7 \\
\hline 12 & AGR & 5,1 & 20,2 & 1,9 cde & $4,6 \mathrm{bcd}$ \\
\hline 13 & COL & 2,7 & 4,3 & 0,5 cde & 1,6 \\
\hline 14 & BER & 4,6 & 11,1 & 2,3 cde & $2,4 \quad$ cdefg \\
\hline 15 & KIK & $14,0 \mathrm{ab}$ & $38,5 \mathrm{a}$ & $3,7 \mathrm{c}$ & $5,0 a b c$ \\
\hline 16 & No. 095 & 4,3 & 9,4 & 0,5 cde & 1,1 \\
\hline 17 & No. 30 & $12,1 \mathrm{abc}$ & 13,9 & 0,4 de & defg \\
\hline 18 & No. 5 & cde & 1,9 & 0,1 & 0,8 \\
\hline 19 & No. 19 & cde & 8,5 & 0,1 & 0,4 \\
\hline 20 & No. 44 & $15,2 \mathrm{a}$ & 14,5 & 0,2 & 1,0 \\
\hline
\end{tabular}

Keterangan: Angka yang diikuti oleh huruf yang sama pada kolom yang sama tidak berbeda nyata pada uji Duncan taraf nyata $5 \%$.

Penentuan skor untuk masing-masing huruf hasil analisis statistik :

$\begin{array}{llll}\text { a, b, c, d, e } & \text { a, b, c, d, e, f } & \text { a, b, c, d, e } & \text { a, b, c, d, e, f, g } \\ \mathrm{a}=25 & \mathrm{a}=25 & \mathrm{a}=25 & \mathrm{a}=25 \\ \mathrm{~b}=20 & \mathrm{~b}=21 & \mathrm{~b}=20 & \mathrm{~b}=22 \\ \mathrm{c}=15 & \mathrm{c}=17 & \mathrm{c}=15 & \mathrm{c}=19 \\ \mathrm{~d}=10 & \mathrm{~d}=13 & \mathrm{~d}=10 & \mathrm{~d}=16 \\ \mathrm{e}=5 & \mathrm{e}=9 & \mathrm{e}=5 & \mathrm{e}=13 \\ & \mathrm{f}=5 & & \mathrm{f}=10 \\ & & \mathrm{~g}=7\end{array}$

asam klorogenat terdeteksi pada umur 1 minggu setelah inokulasi, tetapi tidak terdeteksi lagi pada minggu-minggu berikutnya dan baru terdeteksi lagi pada minggu ke-6. Diduga asam klorogenat yang muncul berturut-turut selama 3 minggu menyebabkan varietas Hertha memiliki ketahanan yang lebih tinggi dibandingkan dengan varietas Granola (Tabel 4).

Asam kafeat tidak terdeteksi pada varietas Hertha dan Granola baik yang diinokulasi maupun yang tidak diinokulasi dengan G. rostochiensis. Hal ini menunjukkan bahwa asam kafeat secara alami tidak terdapat di dalam jaringan akar kedua varietas kentang yang diuji, sehingga kemungkinan besar infeksi nematoda tidak merespon terbentuknya asam kafeat.

Pengamatan Histopatologi. Hasil pengamatan histopatologi pada varietas Hertha dan Granola yang dilakukan pada umur 6 minggu setelah diinokulasi dengan G. rostochiensis menunjukkan adanya kerusakan yang dimulai dari bagian korteks akar, endodermis dan meluas ke xilem yang merupakan bagian dari silinder vaskuler pada penampang melintang irisan jaringan akar kentang (Gambar 1b dan 1d). Kerusakan yang terjadi kemungkinan disebabkan oleh proses migrasi intraseluler 
Tabel 2. Rerata indeks populasi nematoda sista kuning 50 hari setelah inokulasi (hsi)

\begin{tabular}{|c|c|c|c|c|c|c|c|}
\hline No & $\begin{array}{c}\text { Kode } \\
\text { Varietas }\end{array}$ & $\begin{array}{c}\text { sista } \\
\text { dalam } 20 \mathrm{~g} \\
\text { tanah }\end{array}$ & $\begin{array}{c}\sum \text { sista } \\
\text { menempel } \\
\text { pada akar }\end{array}$ & $\begin{array}{c}\text { ¿L3\&L4 } \\
\text { (1 gr akar) }\end{array}$ & $\begin{array}{l}\text { ENematoda } \\
\text { dalam akar }\end{array}$ & $\begin{array}{c}\text { Rerata indeks } \\
\text { populasi } \\
\text { nematoda }\end{array}$ & $\begin{array}{c}\text { Kategori } \\
\text { ketahanan }\end{array}$ \\
\hline 1 & FLS & 5,0 & 5,0 & 12,5 & 16,0 & 9,63 & $\bar{M}$ \\
\hline 2 & DES & 7,5 & 7,0 & 10,0 & 13,0 & 9,37 & M \\
\hline 3 & ERI & 12,5 & 9,0 & 10,0 & 25,0 & 14,12 & $\mathrm{R}$ \\
\hline 4 & $\mathrm{BH}$ & 10,0 & 5,0 & 10,0 & 10,0 & 8,75 & M \\
\hline 5 & FRI & 12,5 & 23,0 & 25,0 & 13,0 & 18,37 & $\mathrm{R}$ \\
\hline 6 & GRA & 13,5 & 17,0 & 10,0 & 23,5 & 17,0 & $\mathrm{R}$ \\
\hline 7 & HER & 5,0 & 5,0 & 7,5 & 7,0 & 6,12 & $\mathrm{~T}$ \\
\hline 8 & LBR & 12,5 & 23,0 & 20,0 & 14,5 & 17,5 & $\mathrm{R}$ \\
\hline 9 & MAN & 10,0 & 5,0 & 5,0 & 7,0 & 6,75 & $\mathrm{~T}$ \\
\hline 10 & ATL & 10,0 & 9,0 & 10,0 & 10,0 & 9,75 & M \\
\hline 11 & CIP & 5,0 & 21,0 & 10,0 & 8,5 & 11,12 & M \\
\hline 12 & AGR & 7,5 & 13,0 & 10,0 & 19,0 & 12,37 & M \\
\hline 13 & $\mathrm{COL}$ & 5,0 & 5,0 & 10,0 & 10,0 & 7,5 & M \\
\hline 14 & BER & 5,0 & 7,0 & 10,0 & 13,0 & 8,75 & M \\
\hline 15 & KIK & 22,5 & 25,0 & 15,0 & 22,0 & 21,12 & $\mathrm{R}$ \\
\hline 16 & No.095 & 5,0 & 7,0 & 10,0 & 10,0 & 8,0 & M \\
\hline 17 & No.30 & 20,0 & 9,0 & 7,5 & 11,5 & 12,0 & M \\
\hline 18 & No.5 & 10,0 & 5,0 & 5,0 & 8,5 & 7,12 & M \\
\hline 19 & No.19 & 10,0 & 7,0 & 5,0 & 7,0 & 7,25 & M \\
\hline 20 & No.44 & 25,0 & 9,0 & 5,0 & 10,0 & 12,25 & $\mathrm{M}$ \\
\hline
\end{tabular}

Keterangan: Ketahanan varietas kentang dikategorikan sebagai berikut:

$0-7,04=$ Tahan $(\mathrm{T}) ; 7,05-14,08=$ Moderat $(\mathrm{M}) ; 14,09-21,12=$ Rentan $(\mathrm{R})$. Rerata indeks tertinggi $(21,12)$ dibagi dengan jumlah kategori ketahanan (3) yaitu 7,04 merupakan interval yang digunakan dalam menentukan kategori ketahanan.

Tabel 3. Retention Factor $(\mathrm{cm})$ dari senyawa yang terkandung pada varietas Hertha dan Granola pada umur 1- 6 minggu setelah diinokulasi dengan $G$. rostochiensis

\begin{tabular}{lcccccc}
\hline \multicolumn{7}{c}{ Retention Factor (dalam cm) } \\
\hline \multicolumn{1}{c}{ Sampel } & Minggu I & Minggu II & Minggu III & Minggu IV & Minggu V & Minggu VI \\
\hline Standar asam klorogenat & 0,71 & 0,67 & 0,67 & 0,82 & 0,78 & 0,71 \\
Hertha inokulasi & 0,67 & 0,71 & $\begin{array}{c}\text { Tidak ada } \\
\text { spot }\end{array}$ & 0,82 & 0,78 & 0,71 \\
Hertha Kontrol & 0,71 & 0,67 & $\begin{array}{c}\text { Tidak ada } \\
\text { spot }\end{array}$ & $\begin{array}{c}\text { Tidak ada } \\
\text { spot }\end{array}$ & 0,71 & Tidak ada \\
Granola Inokulasi & 0,71 & 0,71 & 0,71 & 0,75 & 0,75 & spot \\
Granola Kontrol & 0,71 & 0,71 & 0,67 & Tidak ada & 0,78 & 0,71 \\
Standar asam kafeat & Tidak & 0,86 & 0,86 & 0,86 & 0,86 & 0,89 \\
& digunakan & & & & & \\
\hline
\end{tabular}


Tabel 4. Hasil analisis asam klorogenat pada varietas Hertha dan Granola pada umur 1-6 minggu setelah diinokulasi dengan $G$. rostochiensis

\begin{tabular}{|c|c|c|c|c|c|c|}
\hline \multicolumn{7}{|c|}{ Deteksi asam klorogenat } \\
\hline Sampel & Minggu I & Minggu II & Minggu III & Minggu IV & Minggu V & Minggu VI \\
\hline Hertha inokulasi & - & - & - & + & + & + \\
\hline Hertha kontrol & + & + & - & - & - & - \\
\hline Granola inokulasi & + & - & - & - & - & + \\
\hline Granola kontrol & + & - & - & - & + & + \\
\hline
\end{tabular}

Keterangan: $\quad+$ : terdeteksi asam klorogenat

- : tidak terdeteksi asam klorogenat

nematoda sista di dalam jaringan akar kentang dalam menemukan initial feeding cell atau sel-sel yang cocok untuk dimulainya pembentukan sinsitium.

Pengamatan histopatologi menunjukkan adanya penyerapan warna merah (safranin) yang lebih kuat terjadi pada varietas Hertha dibandingkan dengan varietas Granola. Pengamatan histopatologi ini menggunakan pewarna kombinasi antara safranin (merah) dan fast green (hijau). Salah satu fungsi dari pewarna safranin adalah untuk mewarnai lignin dan selsel yang mengalami lignifikasi, sedangkan fast green digunakan untuk mewarnai sitoplasma dan selulosa (Johansen, 1940; Sass, 1971).

Asam klorogenat merupakan salah satu senyawa turunan asam sinamat (Rhodes \& Wooltorton, 1978). Secara umum asam klorogenat berfungsi menahan serangan mikroorganisme, prekursor lapisan pelindung yang disintesis di dekat kerusakan dan oleh beberapa ahli juga dilaporkan sebagai senyawa antara (prekursor) dalam jalur biosintesis lignin (Harborne, 1987). Lignin adalah salah satu komponen dinding sel yang penting untuk memberikan ketahanan pada tanaman. Asam klorogenat dibutuhkan tanaman dalam proses lignifikasi (Vance et al., 1980)

Hasil analisis TLC (Tabel 4) menunjukkan bahwa asam klorogenat terdapat di dalam varietas Hertha dan Granola. Asam klorogenat pada varietas Hertha kemungkinan lebih banyak dibandingkan dengan varietas Granola setelah diinfeksi G. rostochiensis. Asam klorogenat kemungkinan dapat memberikan ketahanan yang lebih tinggi pada varietas Hertha melalui terbentuknya lignin.

Lignifikasi yang lebih intensif pada jaringan akar varietas Hertha menyebabkan nematoda yang berada di dalam jaringan tidak mampu berkembang dan menyelesaikan siklus hidupnya dengan baik. Hal ini disebabkan nematoda tidak mampu mendegradasi dinding-dinding sel inang yang mengalami lignifikasi atau mungkin terhambat karena aktifitas daya racun senyawa prekursor lignin (asam klorogenat). Lignifikasi juga terjadi pada jaringan akar varietas Granola meskipun sedikit. Hal ini ditunjukkan oleh penyerapan warna merah (safranin) yang kurang intensif. Nematoda masih mampu mendegradasi dinding-dinding sel inang dan berhasil membentuk feeding site. Perkembangan NSK pada varietas Granola menjadi lebih baik, sehingga populasinya menjadi lebih banyak dibandingkan pada varietas Hertha.

\section{SIMPULAN DAN SARAN}

\section{Simpulan}

Berdasarkan hasil penelitian yang dilakukan dapat diambil beberapa kesimpulan yaitu :

1. Hasil uji skrining ketahanan mendapatkan 2 varietas yang tergolong tahan, yaitu varietas Hertha dan Manohara; 13 varietas tergolong moderat yaitu varietas No.30, No.44, No. 5, No.19, Batang Hitam, Agria, Desiree, Berolina, Atlantik, No.095, Cipanas, FLS, dan Colombus, dan 5 varietas yang tergolong rentan yaitu varietas Kikondo, Granola, Erika, LBR, dan Fries.

2. Hasil analisis asam klorogenat dan asam kafeat dengan metode Thin Layer Chromatography (TLC) menunjukkan bahwa asam klorogenat merupakan senyawa yang dihasilkan pada interaksi antara varietas Hertha dan Granola terhadap $G$. rostochiensis. Asam klorogenat pada varietas Hertha menyebabkan terjadinya lignifikasi yang intensif pada jaringan akar yang terserang (korteks, endodermis dan protoxilem), sedangkan pada varietas Granola lignifikasi terjadi kurang intensif. Asam kafeat tidak ditemukan pada kedua varietas tersebut baik sebelum maupun setelah infeksi $G$. rostochiensis. 

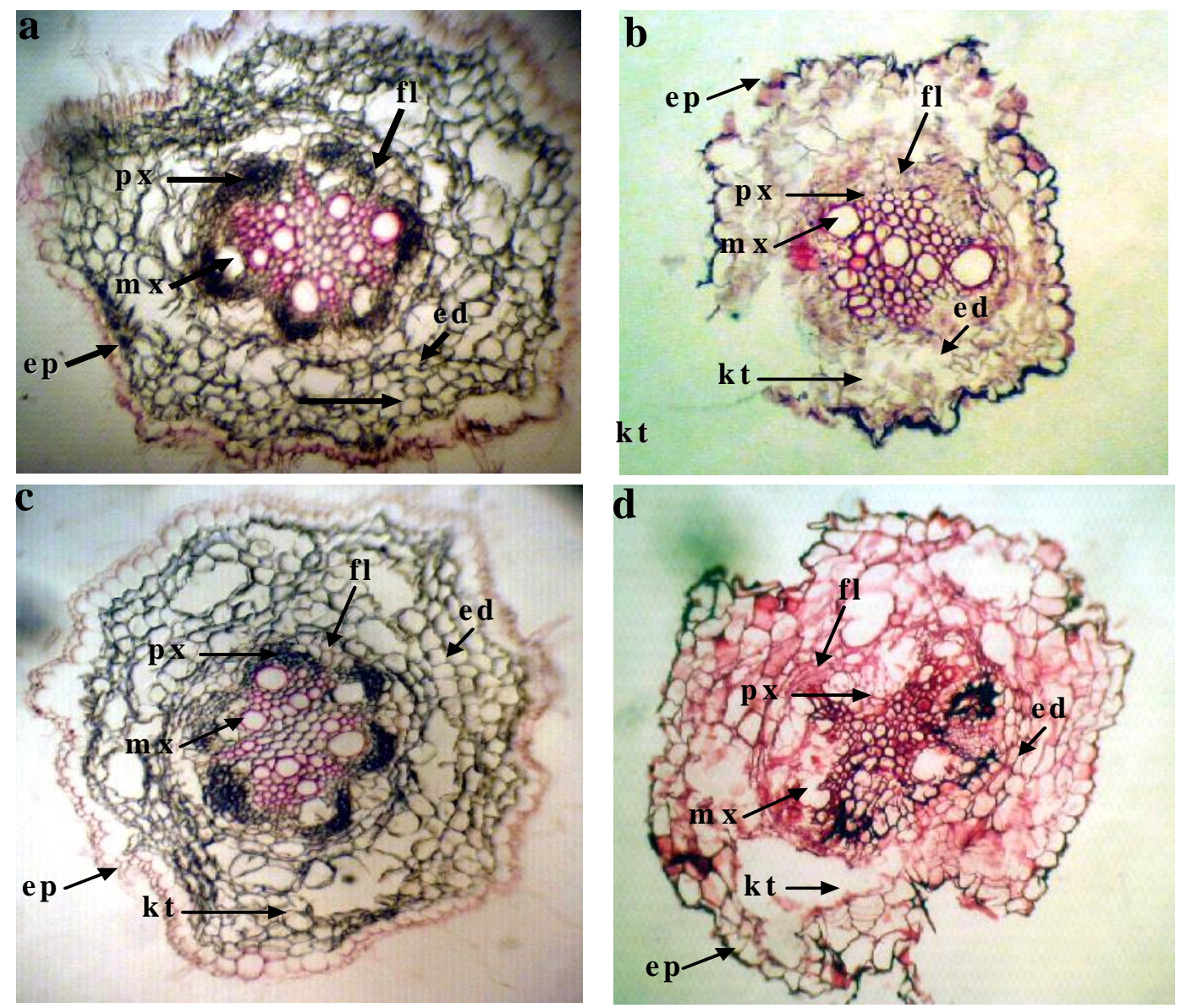

Gambar 1. a. Irisan melintang dari jaringan akar varietas Granola sehat (tanpa inokulasi); b. Irisan melintang jaringan akar varietas Granola pada umur 6 minggu setelah diinokulasi dengan G. rostochiensis. Kerusakan terlihat di daerah korteks, endodermis dan protoxilem (penyerapan warna merah/safranin kurang intensif); c. Irisan melintang dari jaringan akar varietas Hertha sehat (tanpa inokulasi); d. Irisan melintang jaringan akar varietas Hertha pada umur 6 minggu setelah diinokulasi dengan $G$. rostochiensis. Kerusakan terlihat di daerah korteks, endodermis dan protoxilem (penyerapan warna $\mathrm{merah} / \mathrm{safranin}$ lebih intensif). $\mathbf{e p}=$ epidermis, $\mathbf{k t}=$ korteks, $\mathbf{e d}=$ endodermis, $\mathbf{f l}=$ floem, $\mathbf{p x}=$ protoxilem, $\mathbf{m x}=$ metaxilem (Perbesaran 400x)

\section{Saran}

Perlu dilakukan analisis asam klorogenat secara kuantitatif pada varietas Hertha dan Granola.

\section{DAFTAR PUSTAKA}

Byrd, D.W. Jr., T. Kirkpatrick, \& K.R. Barker. 1983. An Improved technique for clearing and staining plant tissue for detection of nematodes. Journal of Nematology 14: $142-143$.

Castillo, M.B., A.P. Rodil, \& B.K. Lim. 1978. Resistance in soybeans (Glycine max L. Merr) to root-knot nematodes and statistical analysis of correlations of assesment paremeters. Phillippine Phytopathology 14: 78 - 88 .

Duncan, L.W. \& J.W. Noling. 1988. Agricultural Sustainability and Nematode Integrated Pest Management. In: K.R. Barker, G.A. Pederson, and G.L. Windham. Plant and Nematode Interaction. American Society of Agronomy, Inc. Wisconsin, USA, p: $267-268$.

Fleg, J.J.M. \& D.J. Hooper. 1986. Extraction of Free Living Stages From Soil. In: Southey, J.F (Eds.) Laboratory Methods for Work With Plant and Soil Nematodes. Ministry of Agriculture, 
Fith and Ford Tech, Bull-Her Majesty Stationery Office. London, p: $5-30$.

Harborne, J. B. 1987. Metode Fitokimia. Penuntun Cara Modern Menganalisis Tumbuhan. Terbitan kedua. Penerbit ITB, Bandung.

Jatala, P. \& J. Bridge. 1990. Nematode Parasites of Root and Tuber Crops. In: M. Luc., R.A. Sikora and J. Bridge. Plant Parasitic Nematodes in Subtropical and Tropical Agriculture. CAB Int, p: $137-180$.

Johansen, D. A. 1940. Plant Microtechnique. McGraw-Hill Books, New York.

Kosuge, T. 1969. The Role of Phenolics in Host Response to Infection. Annual Review Phytopathology 7 : $195-222$.

Rhodes, J. M. \& L. S. C. Wooltorton. 1978. The Biosynthesis of Phenolic Compounds in Wounded Plant Storage Tissues. In : Günter Kahl. Biochemistry of Wounded Tissue. Walter de Gruyter \& Co., Berlin - New York.
Rowe, C.R. 1993. Potato Health Management: A Holistic Approach. Plant Health Management Series, p: $3-6$.

Sass, J. E. 1971. Botanical microtechnique. Third edition. The Iowa State University Press, Iowa.

Shurtleff, M.C. \& C. W. Averre. 2000. Diagnosing plant disease caused by nematodes. The American Phytopathological Society, St. Paul, Minnesota.

Spooner, D. M. \& J.B. Barburg 1994. Potato Genetic Resources : Sources of Resistance and Systematic. American Potato Journal 71: $325-338$.

Vance, C. P., T. K., Kirk, \& R. T. Sherwood. 1980. Lignification as a mechanism of disease resistance. Annual Review of Phytopathology 18: 259 - 88 . 